\title{
EVALUATION OF CONDITIONS FOR QUALITY LOGISTIC SERVICES IN THE AREA OF REFRIGERATED TRANSPORT
}

\section{TERESA GAJEWSKA}

Cracow University of Technology, Kraków, POLAND

e-mail: teresa.gajewska@mech.pk.edu.pl

RECEIVED
ACCEPTED
JEL
CLASSIFICATION

KEYWORDS

ABSTRACT
30 June 2017

15 December 2017

M21, R 40, R49

food products, logistic services, customer satisfaction

Logistic services are evaluated primarily by measuring customer satisfaction. A satisfaction measurement provides information on the operations of an organization and how effective it is in meeting the customers' needs.

The aim of this paper is an evaluation of the organizational conditions of the customer satisfaction level regarding the quality of logistic services within three groups of transport of food products. In turn, the range of the conducted research involved aspects of organizational conditions, such as: effects of the cooperation with a provider of logistic services in the field of transport of food products and the usefulness of the compulsorily implemented management systems in an enterprise.

The studies were carried out based on a research survey questionnaire addressed to purchasers of logistic services. The study subjects were companies that use services for refrigerated transport. The $x^{2}$ test was used to define the relationship between the effects of the cooperation with a service provider and the spatial range of their activities, the respondents' job seniority and education, as well as to estimate the dependence of the evaluation of usefulness of the compulsorily implemented management systems in a company on the spatial range of their activities.

\section{Introduction}

The cold chain is a term applied to food handling and distribution where the product is maintained at suitable conditions all the way from the cooling or freezing process to the point of sale. The transport of cooled produce was one of the first major uses of mechanical refrigeration. Logistics developments have enabled worldwide distribution 
of food under temperature-controlled conditions. The temperature of the commodity must be maintained within specified limits (Hundy, 2008).

The food industry uses important quality management tools, mainly the Good Manufacturing Practices (GMP), Manual Good Hygiene Practices (GHP) and Hazard Analysis Critical Control Point (HACCP).

Transporters and/or containers used for transporting foodstuffs must be kept clean and in good condition, in order to protect food from contamination and should, where necessary, be designed and constructed in such a manner as to permit adequate cleaning and disinfection (Zymberaj, Resyli, Kolgeci, Berisha, 2013).

GMP is a system for ensuring that products are consistently produced and controlled according to quality standards. It is designed to minimize the risks involved in any food production that cannot be eliminated through testing the final product (Finke, 2003).

The Hazard Analysis Critical Control Point (HACCP) philosophy was introduced in European Community legislation in 1993 with Council Directive 93/43/EEC on the hygiene of foodstuffs. It specifies that all business operators shall identify any step in their activities which is critical to ensuring food safety and ensure that adequate procedures are identified, implemented, maintained and reviewed on the basis of the HACCP principles (Panisello, 1999).

Table 1 provides a description of management systems for contact with food, which served as the basis for analysis.

Table 1. Identification quality management tools

\begin{tabular}{ll}
\hline \multicolumn{1}{c}{ Quality management tools } & \multicolumn{1}{c}{ Description } \\
\hline GMP (Good Manufacturing Practices) & $\begin{array}{l}\text { That part of quality assurance aimed at ensuring that products are consistently manufactured to } \\
\text { a quality appropriate to their intended use. It is thus concerned with both manufacturing and quality } \\
\text { control procedures (Anon, 1977). }\end{array}$ \\
& $\begin{array}{l}\text { GPP regulations address issues related to record-keeping, staff training, public hygiene, verification } \\
\text { (control) equipment and investigate (revue) the clamor (Zymberaj, Resyli, Kolgeci, Berisha, 2013). }\end{array}$ \\
HACCP (Hazard Analysis Critical Control Point) & $\begin{array}{l}\text { HACCP is widely recognized in the food industry as a preventive system for managing food safety. } \\
\text { The HACCP system identifies critical control points in the production process that are essential } \\
\text { to monitor and control products safety. HACCPs preventive focus is seen as more effective than } \\
\text { testing a product and then destroying or reworking it (Bata, 2005). }\end{array}$ \\
\hline
\end{tabular}

Source: own research.

\section{Literature review}

The design and maintenance of vehicles and transportation equipment must be such as to ensure that it does not cause the food that it transports to become unsafe. For example, they must be suitable and adequately cleanable for their intended use and capable of maintaining temperatures necessary for the sanitary transport of food (Guide Refrigerated Transport, 2016).

The aim of the research was to assess the organisational conditions for customer satisfaction with the quality of the logistic services in the transport of various groups of products that require controlled temperature in transport.

The writings on the subject offer a number of definitions interpreting logistic services which essentially differ in the degree of their detail (Gołembska, 2010; Kilibarda, 2012). Essentially, a logistic service is an "activity which is intended to satisfy logistic needs of businesses and people" (Dembińska-Cyran, 2005, p. 205). 
A logistic service is a response to the customer's needs and expectations and is about delivering the right product, at the right time, at the right price, and with due service quality (Jałowiec, 2010; Wejers, 2012).

What is being accentuated increasingly frequently in the development of logistics is its link with quality management (Gajewska, 2010). Logistic services are evaluated primarily through customers' satisfaction. A comprehensive definition of customer satisfaction in terms of pleasurable fulfilment is given by Oliver (1997): "...Satisfaction is the consumer's fulfilment response. It is a judgment that a product or service feature, or the product or service itself, provided (or is providing) a pleasurable level of consumption - related fulfilment, including levels of under-or overfulfillment..." (Grigoriudis, Siskos, 2010, p. 4).

The level of the customer's satisfaction reflects the degree to which the total product offered by an organisation satisfies the set of the customer's requirements (Hill, 2003). Indeed, the customer's opinion is the key measure of the quality of logistic services (Mentzer, 2001; Xu, 2008). A satisfaction measurement provides information on the organisation's operation and effective satisfaction of the customers' needs. Satisfaction may be interpreted either from the viewpoint of a specific transaction or a collective point (Saura, 2008). What matters a lot is a subjective nature of the customer's perception of a product or a service which largely depends on the customer's individual characteristics and requirements concerning the product or the service (Sikora, 2010).

\section{Material and research methods}

The analysis of the research took account of the positive and negative impact of the cooperation with a provider of logistic services in the transport of foods. Also obligatory quality management systems in businesses were analysed, to include: Manual Good Hygiene Practices (GHP), Good Manufacturing Practice (GMP) and Hazard Analysis Critical Control Point (HACCP).

The research was done at the end of 2011 and beginning of 2012, and in 2017, and was quantitative in its nature. The research used a questionnaire which were sent out to 1321 purchasers of logistic services. The respondents were customers using logistic services in refrigerated transport, such as manufacturers and distributors of foods, hypermarkets and groceries. A total of 217 questionnaires were obtained electronically and directly from the respondents.

\section{Results and discussion}

The analysis of the organisational conditions started with a presentation of the customers' declarations on the impact of their cooperation with logistic service providers in road transport of foods on their satisfaction with the service quality (Table 2).

Table 2. Evaluation of the impact of cooperation with the company in the field of food products transport

\begin{tabular}{lcccccc}
\hline \multirow{2}{*}{$\begin{array}{l}\text { Impact of cooperation with the logistic service provider } \\
\text { in the field of food products transport on business satisfaction }\end{array}$} & \multicolumn{5}{c}{ Percentage of indications } \\
\cline { 2 - 6 } & no influence & little impact & average impact & huge impact & very big impact \\
& $(0$ pt. $)$ & $(1$ pt. $)$ & $(2$ pt.) & $(3$ pt.) & $(4$ pt.) \\
\hline Positive influence & 3.2 & 11.87 & 15.98 & 40.64 & 28.31 \\
Negative influence & 24.2 & 19.63 & 12.79 & 19.63 & 23.74 \\
\hline
\end{tabular}

Source: own research. 
According to the declarations of service purchasers, for approx. $69 \%$ of them the impact of cooperation with the service provider on their satisfaction was positive, and the impact was evaluated as big and very big. The research also showed a high percentage of customers who saw the impact of their cooperation with logistic service providers on their satisfaction as negative (more than $43 \%$ ). This suggests that nearly half of the respondents are dissatisfied with the fulfilment by providers of logistic services in food product transport of the agreed terms and conditions of contract or the results of their mutual cooperation, and hence conflicts arise between the parties.

The statistical analysis covered the dependence between analysed variables (Table 3 ). The indicator $p$ is the result of the significance test $x^{2}$. The $p$ figure below 0.05 means that there is a statistically significant dependence between the variables under analysis.

Table 3. Dependence evaluation of the impact of cooperation with the company in the field of food products transport on the spatial range of their business activities

\begin{tabular}{|c|c|c|c|c|c|c|}
\hline \multirow{2}{*}{\multicolumn{2}{|c|}{ Impact of the cooperation }} & \multicolumn{4}{|c|}{ Evaluation of impact of cooperation } & \multirow{2}{*}{ P-value } \\
\hline & & local & regional & nationwide & internationalal & \\
\hline \multirow{5}{*}{ 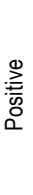 } & no influence & 42.86 & 28.57 & 14.29 & 14.29 & \multirow{5}{*}{0.00004} \\
\hline & little impact & 11.54 & $\underline{46.15}$ & 23.08 & 19.23 & \\
\hline & average & 11.43 & 0.00 & 25.71 & $\underline{62.86}$ & \\
\hline & huge & 11.24 & $\underline{15.73}$ & $\underline{17.98}$ & $\underline{55.06}$ & \\
\hline & very big impact & 6.45 & 9.68 & 29.03 & 54.84 & \\
\hline \multirow{5}{*}{ 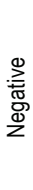 } & no influence & 18.87 & 7.55 & 16.98 & $\underline{56.60}$ & \multirow{5}{*}{0.00893} \\
\hline & little impact & 6.98 & $\underline{27.91}$ & 13.95 & $\underline{51.16}$ & \\
\hline & average & 7.14 & 14.29 & $\underline{39.29}$ & $\underline{39.29}$ & \\
\hline & huge & 0.00 & 13.95 & 23.26 & $\underline{62.79}$ & \\
\hline & very big impact & 17.31 & 15.38 & 26.92 & $\underline{40.38}$ & \\
\hline
\end{tabular}

Explanation: underlined value means numbers of evaluation $>10$.

Source: own research.

Both in the case of a positive and negative impact of the cooperation with the provider the value of the indicator was $p<0.05$. It was demonstrated that the wider the spatial reach of the provider's operations, the greater the positive impact of the cooperation with the logistic provider. However, the dependence between the spatial reach of the provider's operations and a negative impact of the cooperation on the company's activities cannot be clearly defined which is evidenced by the varied ranks.

The statistical analysis also covered the dependence between the respondent's seniority and the evaluation of the relationship with the provider (Table 4).

A significant dependence was demonstrated between the respondents' seniority and the evaluation of a positive and negative impact of the cooperation with the logistic provider on the functioning of the company $(p<0.05)$. The higher the seniority the higher the evaluation of the impact of the relationship with the logistic service provider. It seems that more experienced employees are capable of more analytic evaluation of the mutual relationship with the service provider. 
Table 4. Dependence of the evaluation of the impact of cooperation with a logistic service provider in the field of food products transport on job seniority

\begin{tabular}{|c|c|c|c|c|c|c|}
\hline \multirow{2}{*}{\multicolumn{2}{|c|}{ Impact of cooperation }} & \multicolumn{4}{|c|}{ Evaluation of impact (\%) } & \multirow{2}{*}{ P-value } \\
\hline & & from 0 to 3 years & over 3 to 6 years & over 6 to 9 years & more & \\
\hline \multirow{5}{*}{ 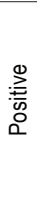 } & no influence & 0.00 & 66.67 & 0.00 & 33.33 & \multirow{5}{*}{0.0252} \\
\hline & little impact & 30.77 & 19.23 & 7.69 & $\underline{42.31}$ & \\
\hline & average & 20.00 & $\underline{34.29}$ & 11.43 & $\underline{34.29}$ & \\
\hline & huge & $\underline{35.96}$ & $\underline{14.61}$ & $\underline{12.36}$ & $\underline{37.08}$ & \\
\hline & very big impact & 48.39 & $\underline{19.35}$ & 12.90 & $\underline{19.35}$ & \\
\hline \multirow{5}{*}{$\begin{array}{l}\stackrel{D}{D} \\
\stackrel{D}{\bar{D}} \\
\stackrel{D}{Z}\end{array}$} & no influence & $\underline{28.30}$ & 18.87 & 9.43 & 43.40 & \multirow{5}{*}{0.0190} \\
\hline & little impact & $\underline{28.57}$ & $\underline{33.33}$ & 9.52 & $\underline{28.57}$ & \\
\hline & average & $\underline{57.14}$ & 14.29 & 7.14 & 21.43 & \\
\hline & huge & $\underline{34.88}$ & $\underline{27.91}$ & 18.60 & 18.60 & \\
\hline & very big impact & $\underline{36.54}$ & 11.54 & 11.54 & 40.38 & \\
\hline
\end{tabular}

Explanation: underlined value means numbers of evaluation $>10$.

Source: own research.

The dependence was also studied between the respondents' education and the impact of the cooperation with the provider of logistic services in the transport of food products. The value of $p$ is the result of the significance test $\chi^{2}$ (Table 5).

Table 5. Dependence of the evaluation of the impact of cooperation with the company in the field of food products transport on the respondent's education

\begin{tabular}{|c|c|c|c|c|c|c|}
\hline \multirow{2}{*}{\multicolumn{2}{|c|}{ The impact of cooperation }} & \multicolumn{4}{|c|}{ Evaluation of impact (\%) } & \multirow{2}{*}{ P-value } \\
\hline & & vocational & secondary & Bachelor's degree & higher education & \\
\hline \multirow{5}{*}{ 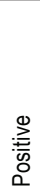 } & no influence & 0.00 & 14.29 & 0.00 & 85.71 & \multirow{5}{*}{0.0070} \\
\hline & little impact & 0.00 & 7.69 & 7.69 & $\underline{84.62}$ & \\
\hline & average & 11.43 & 17.14 & 17.14 & $\underline{54.29}$ & \\
\hline & huge & 2.25 & $\underline{24.72}$ & $\underline{15.73}$ & $\underline{57.30}$ & \\
\hline & very big impact & 3.23 & 16.13 & $\underline{33.87}$ & $\underline{46.77}$ & \\
\hline \multirow{5}{*}{ 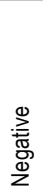 } & no influence & 7.55 & 18.87 & $\underline{20.75}$ & $\underline{52.83}$ & \multirow{5}{*}{0.0040} \\
\hline & little impact & 0.00 & 18.60 & 4.65 & $\underline{76.74}$ & \\
\hline & average & 7.14 & 0.00 & 25.00 & $\underline{67.86}$ & \\
\hline & huge & 0.00 & 18.60 & 18.60 & $\underline{62.79}$ & \\
\hline & very big impact & 3.85 & $\underline{28.85}$ & $\underline{28.85}$ & $\underline{38.46}$ & \\
\hline
\end{tabular}

Explanation: underlined value means numbers of evaluation $>10$.

Source: own research.

The statistical analysis demonstrated that there is a significant dependence between the analysed variables $(p<0.05)$. It was noted that the higher the employees' education the higher their evaluation of the impact of the cooperation with the service provider on their company's satisfaction. It was also demonstrated that the higher the employees' education the higher their evaluation of the negative impact of the relationship with the logistic provider 
on the satisfaction. The above dependencies are correct because employees with higher education have the relevant knowledge and higher awareness and hence are more capable of evaluating the impact of the cooperation between the customer and the service provider.

The respondents' opinions were also used to evaluate the usefulness of the obligatory management systems implemented with the service providers (Table 6).

Table 6 . Evaluation of the usefulness of the implemented management systems

\begin{tabular}{|c|c|c|c|c|c|}
\hline \multirow{2}{*}{$\begin{array}{l}\text { Management } \\
\text { systems }\end{array}$} & \multicolumn{5}{|c|}{ Percentage of indications } \\
\hline & $\begin{array}{c}\text { very little usefuless } \\
\text { (1 pt.) }\end{array}$ & $\begin{array}{c}\text { little usefulness } \\
\text { (2 } 2 \mathrm{pt} \text { ) }\end{array}$ & $\begin{array}{c}\text { average usefulness } \\
(3 \text { pt. })\end{array}$ & $\begin{array}{l}\text { high usefulness } \\
\text { (4 pt.) }\end{array}$ & $\begin{array}{l}\text { very high usefulness } \\
\text { (5 pt.) }\end{array}$ \\
\hline GHP & 5.09 & 11.11 & 22.69 & 37.96 & 23.15 \\
\hline HACCP & 8.29 & 10.60 & 18.89 & 32.72 & 29.49 \\
\hline GMP & 11.11 & 15.28 & 29.17 & 26.39 & 18.06 \\
\hline
\end{tabular}

Explanation: Due to the fact that respondents did not provide an answer the attempt is: for GHP and GMP, N = 216, for HACCP N $=217$.

Source: own research.

Nearly $62 \%$ of the respondents found the GHP and the HACCP useful and very useful. For more than $44 \%$ of the respondents, the implementation in a transport company of the GHP was considered useful and very useful. It is to be noted further that none of the respondents mentioned uselessness of the implementation of any of the systems under analysis for the purposes of service quality improvement.

The statistical analysis covered the dependence of the evaluation of the management systems that were implemented on the spatial reach of the service purchasers' activities. The value $p$ is the result of the significance test $X^{2}$ (Table 7).

Table 7. Dependence evaluation of the usefulness of GHP and HACCP on the spatial range of business activities (logistic purchasers)

\begin{tabular}{|c|c|c|c|c|c|c|}
\hline \multirow{2}{*}{\multicolumn{2}{|c|}{$\begin{array}{l}\text { Level of usefulness of } \\
\text { systems }\end{array}$}} & \multicolumn{4}{|c|}{ Evaluation of usefulness (in \%) } & \multirow{2}{*}{$\mathrm{P}$-value } \\
\hline & & local & regional & nationwide & international & \\
\hline \multirow{5}{*}{$\begin{array}{l}\text { 䓀 } \\
\text { 心 }\end{array}$} & no influence & 9.09 & 18.18 & 36.36 & 36.36 & \multirow{5}{*}{0.95191} \\
\hline & little impact & 12.50 & 16.67 & 20.86 & $\underline{50.00}$ & \\
\hline & average & 8.16 & 16.33 & 20.41 & $\underline{55.10}$ & \\
\hline & huge & $\underline{14.63}$ & $\underline{17.07}$ & $\underline{19.51}$ & $\underline{48.78}$ & \\
\hline & very big impact & 8.00 & 12.00 & $\underline{28.00}$ & $\underline{52.00}$ & \\
\hline \multirow{5}{*}{$\begin{array}{l}\text { 엉 } \\
\text { 立 }\end{array}$} & no influence & 5.56 & 44.44 & 5.56 & 44.44 & \multirow{5}{*}{0.00355} \\
\hline & little impact & 13.04 & 8.70 & 26.09 & $\underline{52.17}$ & \\
\hline & average & 9.76 & $\underline{29.27}$ & 21.95 & $\underline{39.02}$ & \\
\hline & huge & $\underline{16.90}$ & 11.27 & $\underline{23.94}$ & $\underline{47.89}$ & \\
\hline & very big impact & 6.25 & 6.25 & $\underline{26.56}$ & $\underline{60.94}$ & \\
\hline
\end{tabular}

Explanation: underlined value means numbers of evaluation $>10$.

Source: own research. 
The statistical analysis demonstrated no impact of the spatial reach of the company's activities on the evaluation of the usefulness of the Good Hygienic Practices implemented with the company (service provider). The values of $p$ were, in the analyses cases, above 0.05 . What was demonstrated, however, was a dependence of the evaluations of the usefulness of the implementation of the HACCP system on the reach of the customer's activity. It was found that the greater the spatial reach of the company's operations the higher the evaluation of implementation of the GHP (Manual Good Hygiene Practices) and the HACCP system.

\section{Conclusions}

In conclusion to the analysis, it is to be noted that approx. $69 \%$ of the respondents consider the impact of the cooperation with the service provider on the functioning of the company and its satisfaction as positive. A significant dependence was demonstrated of the impact of the cooperation on the satisfaction with the service quality on the spatial reach of the service purchaser's operations. The wider the spatial scope of activities (from local to international), the higher the evaluation of the positive impact of the relationship with the service provider. Further, a correspondence was identified between the evaluations of a positive impact and the respondents' seniority and education. As regards the usefulness of the obligatory management systems to be introduced by service providers, concerning the Good Hygiene Practices and the HACCP system, the respondents mentioned their usefulness at the level of above 3.5 points (that is between average and high usefulness). Hence, none of the management systems introduced obligatorily in service providers which were analysed obtained an average of high usefulness. What was demonstrated, in the other hand, was a significant dependence of the evaluations of the usefulness of the implementation of the HACCP system with the provider on the spatial reach of the purchaser of logistic services in the area of food product transport.

\section{Acknowledgments}

The research and the results presented herein, done under DS-M8/356/2016/DS-M, have been financed from the research subsidy granted by the Ministry of Science and Higher Education.

\section{References}

Anon, (1997). Guide to Good Pharmaceutical Manufacturing Practice, 2nd edition. London: HM Stationery Office.

Bata, D., Drosinos, E.H., Athanasopoulos, P., Spathis, P. (2006). Cost of GHP improvement and HACCP adoption of an airline catering company. Food Control, 17, 414-419.

Dembińska-Cyran, l., Jedliński, M. (2005). Usługi logistyczne. In: S. Flejtarski, A. Panasiuk, J. Perenc, G. Ros (eds.), Współczesna ekonomika usług. Warszawa: Wydawnictwo Naukowe PWN.

Finke, M., Schulz, H. (2003). Z.U. Aktuelles GMP - Regularien (GMP regulatory documents: current issues). Pharmazeutische Industrie, 10 (65), 1065-1069.

Gajewska, T. (2010). Kryteria oceny jakości usług logistycznych. In: T. Sikora (ed.) Zarządzanie jakością - doskonalenie organizacji (pp. 30-38), Kraków: PTTŻ Publishing.

Gołembska, E. (ed.) (2010). Kompendium wiedzy o logistyce. Warszawa: Wydawnictwo Naukowe PWN.

Grigoroudis, E., Siskos, Y. (2010). Customer Satisfaction Evaluation. Methods for Measuring and Implementing Service Quality. Springer.

Hill, A.J. (2003). Pomiar satysfakcji i lojalności klientów. Kraków: Oficyna Ekonomiczna.

Hundy, G.F., Trott, A.R., Welch, T.C. (2008). Refrigeration and Air-Conditioning (Fourth Edition). Butterworth Heinemann.

Jałowiec, T., Nowak, I. (2010). Jakość w outsourcingu usług logistycznych. Logistyka, 3, 70-75. 
Kilibarda, M., Andrejic, M. (2012). Logistics service quality impact on customer satisfaction and loyalty. $2^{\text {nd }}$ International Conference on Supply Chains (ICSC). Belgrade. Serbia.

Mentzer, J.T., Flint D.J., Hult, G.T.M. (2001). Logistics Service Quality as a Segment Customized Process. Journal of Marketing, 65, 82-104.

Oliver, R.L. (1977). Effect of expectation and disconfirmation on postexposure product evaluations: An alternative interpretation. Journal of Applied Psychology, 4 (62), 480-486.

Panisello, P.J., Quantick, P.Ch., Knowles, M.J. (1999). Towards the implementation of HACCP: results of a UK regional survey. Food Control, 10, 87-98.

Saura, J.G., Frances, D.S., Contri, B.G., Blasco, F.M. (2008). Logistics service quality: a new way to loyalty, Industrial Management \& Data Systems, 5 (108), 650-668.

Sikora, T., Nowicki, P. (2010). Czynniki kształtujące satysfakcję klienta oraz korzyści z pomiaru satysfakcji klienta w procesie doskonalenia jakości. In: T. Sikora (ed.) Zarządzanie jakością-doskonalenie organizacji (pp.171-178). Kraków: PTTŻ Publishing.

Xu, J. (2008). Logistics Service Quality Analysis Based on Gray Correlation Method. International Journal of Business and Management, 1 (3), 58-61.

Wejers, S., Glöckner, H., Pietras R. (2012). Logistic service providers and sustainable physical distribution. LogForum, 2 (8), $157-165$.

Zymberaj, I., Resyli, P., Kolgeci, M., Berisha, G. (2013). Manual Good Hygiene Practices (GHP). Agjencia e Ushqimit dhe Veterinarise (AUV).

Cite this apticle aS: Gajewska, T. (2018). Evaluation of conditions for quality logistic services in the area of refrigerated transport. European Journal of Service Management, 2 (26), 87-94. DOI: 10.18276/ejsm.2018.26-11. 